\title{
Groundwater response to precipitation extremes: the case of the "Vaia" storm (Eastern Italian Alps)
}

\section{La risposta delle acque sotterranee a precipitazioni estreme: il caso della tempesta "Vaia" (Alpi Orientali)}

\author{
Giorgia Lucianetti, Lucia Mastrorillo, Roberto Mazza, Piergiovanni Partel
}

\begin{abstract}
Riassunto: Si prevede che nelle regioni alpine le precipitazioni estreme aumenteranno di intensità a causa dei cambiamenti climatici. Molti studi hanno analizzato l'impatto di questi fenomeni sul rischio di alluvionamento, mentre pochi si sono occupati del loro impatto sulle acque sotterranee. In questo lavoro è stata analizzata la risposta degli idrogrammi di tre sorgenti a un episodio di precipitazione estrema che è avvenuto nel Nord Italia ad ottobre 2018. E' stato osservato che la nuova acqua d'infiltrazione dell' intenso evento di precipitazione ha contribuito ad alimentare il flusso di base invernale, aumentandone il volume fino all' $85 \%$ rispetto alle condizioni normali. E' stato inoltre riscontrato che la risposta delle acque sotterranee a precipitazioni intense sembra essere influenzata dal mezzo in cui circola. Una sorgente di alta quota alimentata da un acquifero carbonatico e fratturato risponde in modo rapido all'input della tempesta, mentre le sorgenti emergenti alla base delle pendici delle montagne (drenanti acquiferi carbonatici fratturati e depositi porosi) mostrano una risposta ritardata. I risultati di questo lavoro sono importanti per l'analisi della disponibilità idrica futura e per capire l'impatto di eventi estremi sulla circolazione idrica sotterranea.
\end{abstract}

Keywords: hydrograph analyses, climate change, precipitation extremes, Pale di San Martino.

Parole chiave: analisi degli idrogrammi, cambiamenti climatici, precipitazioni estreme, Pale di San Martino.

\author{
Giorgia LUCIANETTI 莑早 \\ Ente Parco Naturale Paneveggio Pale di San Martino, Villa Welsperg \\ località Castelpietra, 2, 38054 Primiero San Martino Di Castrozza (Tn) Italy \\ giorgia.lucianetti@parcopan.org \\ Dipartimento di Scienze, Università degli Studi Roma Tre, Largo S. Leonardo \\ Murialdo 1, 00146 Roma, Italy \\ giorgia.lucianetti@uniroma3.it
}

Lucia MASTRORILLO, Roberto MAZZA

Dipartimento di Scienze, Università degli Studi Roma Tre, Largo S. Leonardo Murialdo 1, 00146 Roma, Italy

\section{Piergiovanni PARTEL}

Ente Parco Naturale Paneveggio Pale di San Martino, Villa Welsperg località Castelpietra, 2, 38054 Primiero San Martino Di Castrozza (Tn) Italy

Ricevuto/Received: 21 October 2019-Accettato/Accepted: 17 December 2019 Pubblicato online/Published online: 20 December 2019

This is an open access article under the CC BY-NC-ND license:

http://creativecommons.org/licenses/by-nc-nd/4.0/

(C) Associazione Acque Sotterranee 2019
Abstract: Extreme precipitation events are expected to increase in intensity in Alpine regions due to climate change. While many studies have analyzed the impact of these phenomena on flooding risk, very few deal with their effect on groundwater. This work analyzes the bydrograph response of three springs to an extreme storm, which occurred in Northern Italy in October 2018. We observed that the newly infiltrated storm water contributed to feeding the winter baseflow, increasing its volume up to $85 \%$ compared to normal conditions. It was also found that the response of groundwater to heavy precipitation seems to be influenced by the type of media. A bigh-altitude spring belonging to the fractured carbonate aquifer shows a quick response to the storm input, while springs outflowing at the base of the mountain slopes (mixed fractured carbonate and porous deposits) exhibit a delayed response. Results are important when analyzing future water availability and to better understand the impact of extreme events on groundwater flow.

\section{Introduction}

Global warming is expected to produce several effects on the European Alpine climate, producing snow recession at low elevation (Beniston 2012) and a greater portion of liquid to solid precipitation (Confortola et al. 2013). While regional climatic models agree with a reduction of summer precipitation and thus increased drought stress in the future (Calanca 2007; Gobiet et al. 2014), precipitation extremes, such as those events with a 10 -year return period, are expected to increase in intensity (Brönnimann et al. 2018; Asadieh and Krakauer 2015). Extreme weather events in the Alpine region are responsible for flooding and landslides, and have direct social and economic impact. For this reason, studies on precipitation extremes frequently deal with natural hazards, especially landslides and flooding risk (Yang et al. 2016; Dankers et al. 2014; Kron et al. 2019). Therefore, while knowledge on surface runoff is good, studies on the groundwater response to precipitation extremes are rare (Zhangh et al. 2016). The aim of this work, is to contribute to fill this gap by analyzing data from an exceptional storm (Storm "Vaia"), thanks to a daily discharge dataset recorded from a spring monitoring network. The exceptional event occurred during the no-recharge period of the alpine aquifers, therefore the alteration of the spring recession curves was analyzed in order to achieve new knowledge on the drainage processes. Recession analysis is a fundamental tool in hydrogeology and has been used successfully to study the behavior of karst aquifers and to describe flow components (Bonacci 1993; Padilla et al. 1994; Baedke and Krothe 2001; Fiorillo 2009). 
Also, the comparison of different recession curves in the same spring allows understanding which recession parameters represent inherited aquifer characteristics (Amit et al. 2002). In the studied area, the three studied springs are utilized for drinking water supply. Hence, quantification of extreme events and understanding their effect on groundwater storage is fundamental for ensuring suitable a sustainable water management planning.

\section{Study area}

The study area is located in the Dolomites Mountains (Eastern Italian Alps). The elevation ranges between $1000 \mathrm{~m}$ a.s.l. at the valley floor and over $2900 \mathrm{~m}$ a.s.l. at the highest peaks, respectively the Pala di San Martino and the Canali Peak. The geology of the area consists in a thick sequence of Middle Triassic dolomites, forming the main fractured and karst aquifer (Fig. 1). Below, clay-rich evaporitic and terrigenous formations act as the regional aquiclude (Lucianetti et al. 2019). Rockfall deposits cover the mountain slopes, creating a transition between the vertical rock faces and the valley-fill deposits, mainly glacial morains and alluvial deposits. Water outflowing from the carbonate aquifer is transferred to the valley-fill deposits, which host multilayer porous aquifers. The Pradidali stream originates at the Pradidali springs (1456 $\mathrm{m}$ a.s.l.) and it flows until the confluence with the Canali stream. The Pradidali springs group drains water exclusively from the carbonate aquifer and comprises several seepages and a main emergence point (Pra in Fig.1). The Acque Nere springs (1150 $\mathrm{m}$ a.s.l.) emerge in the Canali valley at the base of a large debris cone below Mt. Feltraio, in correspondence with clay layers of the moraine deposit. Two spring houses, Acq1 and Acq2 feed the local water supply. Groundwater emerges also diffusively along the riverbed as gaining reaches along the streams. From a climatic point of view, the mean annual temperature for the 2014-2018 period is $7.9^{\circ} \mathrm{C}$ and the mean annual precipitation is approximately $1480 \mathrm{~mm}$ at the Tonadico station (1045 $\mathrm{m}$ a.s.l.), while it is respectively $7.1^{\circ} \mathrm{C}$ and $1735 \mathrm{~mm}$ at the Cereda station (1322 $\mathrm{m}$ a.s.l.) for the same time period.

\section{The storm Vaia}

Between October $27^{\text {th }}$ and $29^{\text {th }}$ of 2018, an extreme meteorological event known as storm "Vaia" hit the study area. The 72 hours rainfall quantity was exceptional, with peaks above $600 \mathrm{~mm}$ in two stations of the Trento Province, including one station, the Cereda station, located close to the study area (Trenti 2018). In the Tonadico station, the 72 hours cumulative amount was $361 \mathrm{~mm}$, corresponding to $25 \%$ of the yearly average amount. The storm caused flood waves in several streams, landslides and intense forest damage due to the wind gusts exceeding $200 \mathrm{~km} \mathrm{~h}^{-1}$ (http://www. meteotriveneto.it). In the North of Italy the loss of standing trees was estimated to be 8.5 million cubic meters (Chirici et al. 2019). In the study area the damage was concentrated in the Canali valley, both in the upper part of the valley and near the confluence with the Pradidali stream, where the Canali stream overflowed its banks destroying the main road. The storm followed a dry and exceptionally warm period, which was characterized by Foehn winds and fires (http://www.nimbus.it/eventi/2018/181024CaldoRecord2. htm). After the storm and until the following April 2019 the precipitation amount was very low, with only one small event in February. These peculiar weather conditions allowed to clearly distinguish in the spring recession phase the part of the discharge volume attributed to the storm.

\section{Methods \\ Hydrological monitoring}

The monitoring network consists of three springs equipped with water level sensors: Pradidali spring and Acque Nere springs (Pra, Acq1, Acq2 in Fig. 1). Monthly discharge measurements were carried out using a magnetic current meter (OTT Nautilus) to extrapolate the stage-discharge relationships. The rating curves were used to convert level data into discharge time series (hydrographs). Data presented in the paper refer to the period between September 2017 and May 2019. Precipitation and temperature for the same time interval were derived from the official weather service (meteotrentino.it) at the Tonadico station.

\section{Data analysis}

The shape of the hydrographs was compared to climatic data to understand the general response of the groundwater to recharge inputs. The discharge regime of all springs was characterized by the spring coefficient of variation parameter (CV) (Buczyński 2018)

$$
C V=\frac{\sigma}{\theta} \times 100
$$

where $\sigma$ is the standard deviation and $\theta$ is the arithmetical mean of spring discharge values. Springs with lower values of CVs tend to be more stable. Then, the master recession curves (MRCs) for each spring were constructed using recession periods characterized by more or less unaffected conditions (i.e. without recharge impulses that could interrupt the recession signal). Individual recession sets were assembled together by moving them individually on the horizontal axis to find the most representative MRC, following the approach of Malik and Vojtkova (2012). In this step, the storm recession curve was discarded to obtain MRCs in normal weather conditions. Being aware that more years are usually required to build representative MRCs, we were limited by the availability of a two-year dataset. However, the pre-storm period reflects acceptable conditions to allow us to build average MRCs with sufficient accuracy. Based on the MRCs, the recession parameters of each spring were defined and attributed to the different flow components of the groundwater system (Kresic and Bonacci 2010; Malik 2015). The several phases of the recession period were described both with exponential equations and with linear equations. Recession parameters of the different springs were compared with each other to verify 


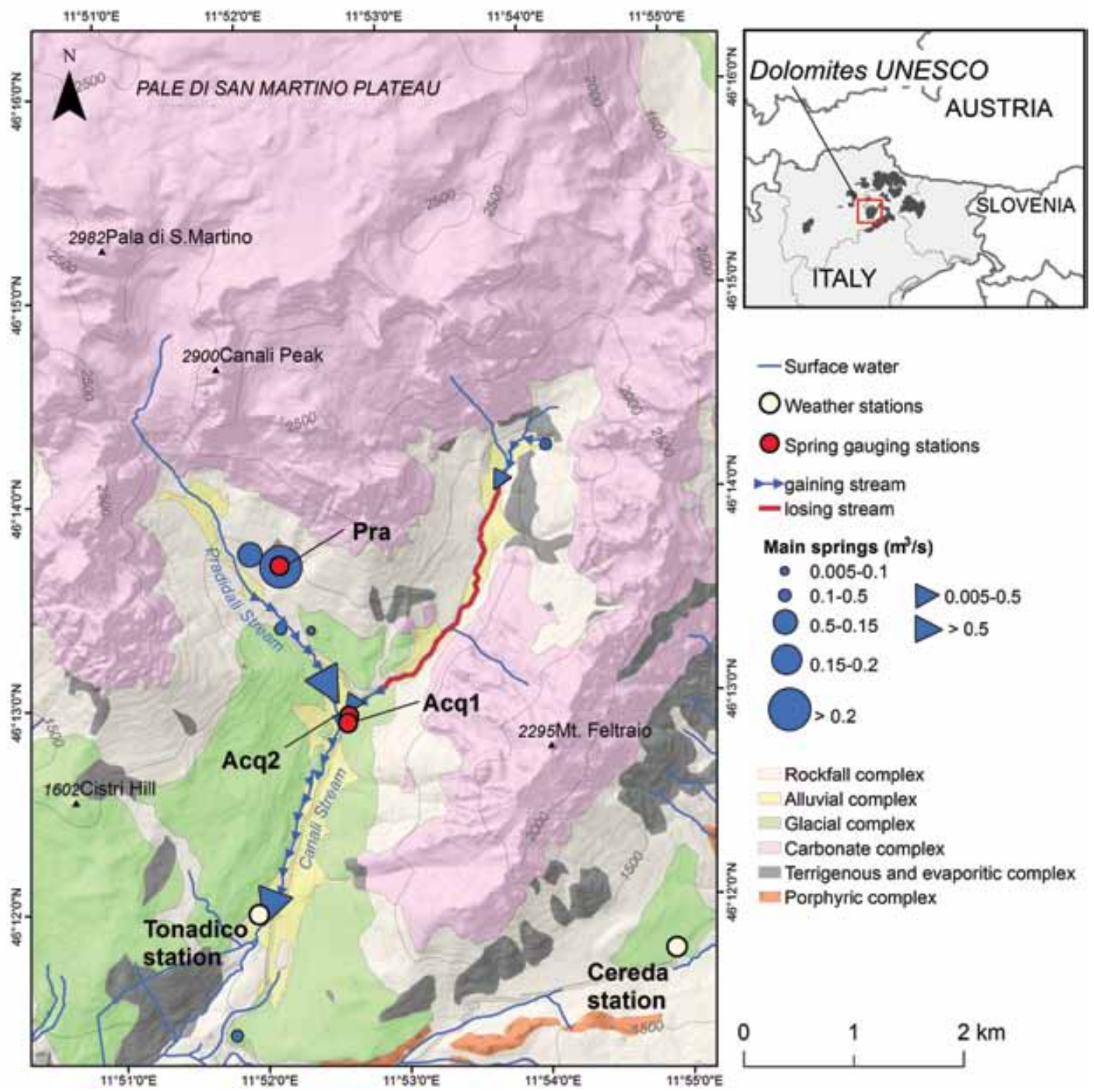

Fig. 1 - Hydrogeological setting of the study area (modified after Lucianetti et al. 2019) and location of the monitoring network. The pink color represents the carbonate complex, which is formed mainly by middle Triassic dolomites and represents the main fractured and karst aquifer, while the grey color represents the terrigenous and evaporitic complex forming the main regional acquiclude. The porous valley-fill deposits consist of interdigitated rockfall, alluvial and glacial deposits. Blue dots and blue triangles refer respectively to the main point springs and to submerged springs (i.e. gaining streams).

Fig. 1 - Assetto idrogeologico dell'area di studio (modificato da Lucianetti et al. 2019) e ubicazione della rete di monitoraggio. Il colore rosa rappresenta il complesso carbonatico costituito principalmente da dolomie triassiche e rappresenta l'acquifero principale fessurato e carsificato, mentre il colore grigio rappresenta il complesso terrigeno ed evaporitico che forma l'acquicludo regionale. I depositi porosi di riempimento della valle comprendono depositi di versante, alluvionali e glaciali interdigitati tra loro. I cerchi blu e i triangoli blu rappresentano rispettivamente le sorgenti puntuali e le sorgenti lineari.

if they were affected by the different geological features of the springs. Then, to show if the recession parameters change during wet years or remain constant, the storm recession curve which lasted until the following April 2019 was analyzed. The previously built MRC for each spring was joined to the recession phase which started in September 2018 (interrupted by the storm arrival) in order to show how the recession curve would have continued without the storm influence. This allowed to compare the two recession curves: the real post-storm recession and the presumed "unaffected" recession curve.
Based on an in-house Matlab script the "unaffected baseflow volume" (unaffected $\mathrm{V}_{\mathrm{b}}$ ) and the "baseflow volume after the storm" ( $\mathrm{V}_{\mathrm{b}}$ after storm) were calculated for each spring.

The Matlab function computes the numerical integration of the discharge and was applied first to the unaffected discharge time series (i.e. to the MRC joined to the recession which started in September 2018) in order to calculate the unaffected $\mathrm{V}_{\mathrm{b}}$ and then to the real discharge time series to calculate the $\mathrm{V}_{\mathrm{b}}$ after storm. To compare the results between different springs the same time interval at the end of the 
winter recession phase (31 days before the first recharge input) was chosen for the calculations. For instance, for the Acq2 spring the first recharge input was observed on 05/04/2019, therefore the baseflow volumes were calculated considering the discharge between 04/03/2019 and 04/04/2019. To compute the baseflow volume variations ("extra $\mathrm{V}_{\mathrm{b}}$ with storm") the unaffected $\mathrm{V}_{\mathrm{b}}$ was subtracted from the $\mathrm{V}_{\mathrm{b}}$ after storm.

\section{Results and discussion}

\section{Spring regime and general characteristics}

The daily discharge recorded for the monitored springs is represented in Fig. 2a. During the period under observation, some analogies can be recognized between the spring hydrographs. All the springs appear to be strongly influenced by snow, as high-flow starts in correspondence of the melting season (April and May), when the temperature rises above $0{ }^{\circ} \mathrm{C}$ (Fig. 2b). This causes a sudden increase in discharge. In late summer, when all the snow cover is melted the spring discharge starts to decrease towards the winter months. In autumn (September, October and November) the hydrograph is affected mainly by rain, as the temperature is usually above $0{ }^{\circ} \mathrm{C}$.

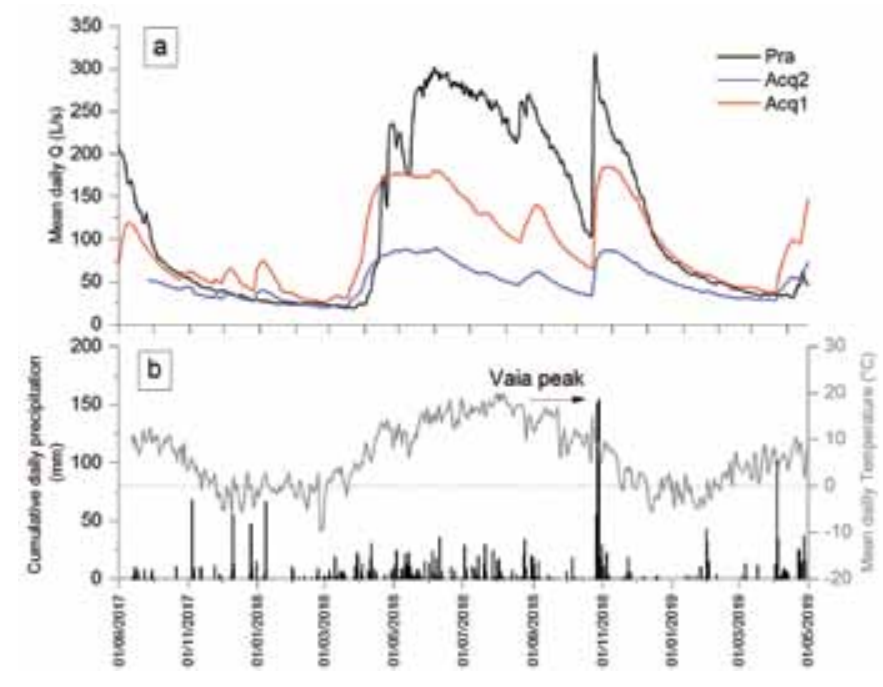

Fig. 2 - a) Daily hydrographs of the monitored springs b) climatic data at the Tonadico station. See Fig. 1 for the location.

Fig. 2 - a) Idrogramma giornaliero delle sorgenti monitorate b) dati climatici della stazione di Tonadico. Vedere la Fig.1 per l'ubicazione.

Low-flow periods occur during the winter months (January, February and March), when recharge is prevented by the snow cover and frozen soil. Average spring characteristics are reported in Tab.1. Among the monitored springs, Pra spring shows the highest mean discharge $(152 \mathrm{~L} / \mathrm{s})$ and the greatest discharge variation $(\mathrm{CV} 64 \%)$ as well as a fast and steep response to precipitation. Acq2 and Acq1 springs show a delayed reaction to recharge inputs and a more buffered curve. Acq2 is characterized by the lowest average discharge $(55 \mathrm{~L} / \mathrm{s})$ and a more stable regime (CV 39\%).
Tab. 1 - Principal characteristics of the springs referred to the bydrogeological year 2018-2019 (from 01/03/2018 to 01/04/2019).

Tab. 1 - Caratteristiche principali delle sorgenti monitorate riferite all'anno idrologico 2018-2019 (da 01/03/2018 a 01/04/2019).

\begin{tabular}{|l|c|c|c|c|c|c|}
\hline $\begin{array}{c}\text { Spring } \\
\text { code }\end{array}$ & $\begin{array}{c}\text { Official } \\
\text { name }\end{array}$ & $\begin{array}{c}\text { Elevation } \\
{[\mathrm{m} \text { a.s.1. }]}\end{array}$ & $\begin{array}{c}\text { Mean Q } \\
{[\mathrm{L} / \mathrm{s}]}\end{array}$ & $\begin{array}{c}\text { Min Q } \\
{[\mathrm{L} / \mathrm{s}]}\end{array}$ & $\begin{array}{c}\text { Max Q } \\
{[\mathrm{L} / \mathrm{s}]}\end{array}$ & $\begin{array}{c}\mathrm{CV} \\
(\%)\end{array}$ \\
\hline Pra & Pradidali & 1456 & 152 & 19 & 317 & $64 \%$ \\
\hline Acq1 & $\begin{array}{c}\text { Acque } \\
\text { Nere }\end{array}$ & 1154 & 107 & 25 & 185 & $48 \%$ \\
\hline Acq2 & $\begin{array}{c}\text { Acque } \\
\text { Nere }\end{array}$ & 1150 & 55 & 19 & 90 & $39 \%$ \\
\hline
\end{tabular}

\section{Recession analysis in normal conditions}

The MRCs allowed identifying the different flow components of the springs (Fig. 3). In all cases, a single recession coefficient value seems unable to explain all the draining processes.

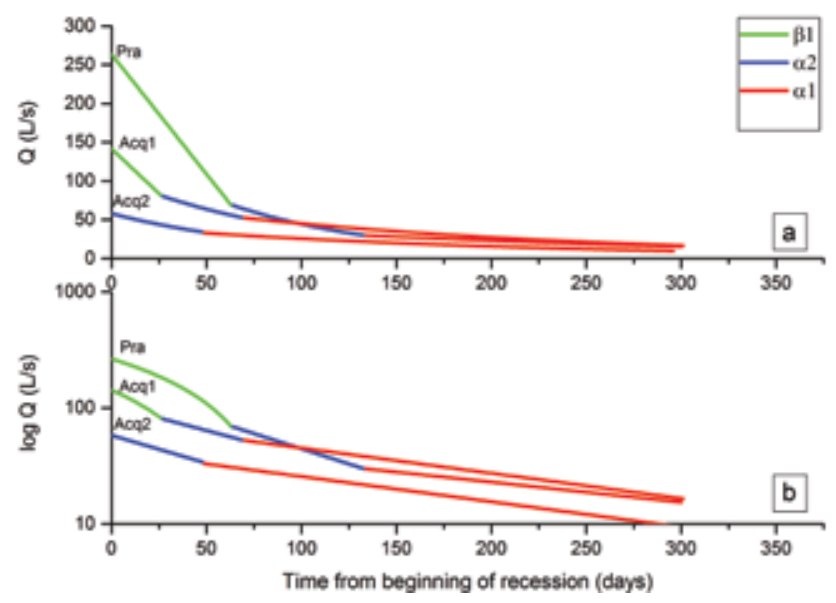

Fig. 3 - Master recession curves of the monitored springs represented in a normal plot (a) and in a semilogarithmical plot (b).

Fig. 3 - Curve master di recessione delle sorgenti monitorate, rappresentate in un grafico normale (a) e in un grafico semilogaritmico (b).

Three different regimes have been identified for the Pra and Acq1 springs as the recession curve can be approximated by two exponential functions and one linear function, with three recession coefficients $\left(\alpha_{1}\right.$ and $\alpha_{2}$ for the exponential regimes and $\beta_{1}$ for the linear regime). Only two exponential regimes have been recognized for the Acq2 recession curve. As suggested by Milanovic (1976) and following literature, the coefficients can be interpreted as flow from three types of porosity, represented by the three recession coefficients of successive orders of magnitude. $\beta_{1}$ is a reflection of rapid outflow karst conduit and open fractures, $\alpha_{2}$ is interpreted as mixed flow in well connected fissures and $\alpha_{1}$ can be considered to be a response to the drainage of water from pores and narrow fissures. This last exponential term with the smallest recession coefficient corresponds to the baseflow no more fed by the meteoric recharge. The springs show similar baseflow parameters, with $\alpha_{1}$ between 0.004 and 
0.005 indicating a common hydraulic property attributed to the same basal regional aquifer (the carbonate aquifer). The contrast between the MRCs is highest during the first stage of the recession limb which is characterized by the rapid flow component $\left(\beta_{1}\right)$ and is representative of the local properties of each spring. Pradidali spring is dominated by the quickflow for the first 63 days after the beginning of the recession. On the contrary, in the Acq 2 spring, the rapid flow stage is absent. Acq1 displays an intermediate behavior, with a small volume of quickflow, which is rapidly released after the first 26 days from the beginning of the recession. Likely, the quickflow component is present also in the carbonate aquifer draining the Acque Nere springs, but it is progressively buffered by the slope deposits, which transfer the groundwater flow from the carbonate aquifer to the valley-fill porous aquifers. Springs influenced by the porous deposits are therefore progressively more stable (CV 64\%, 48\% and 39\% for the Pra, Acq1 and Acq2 respectively). A summary of the recession parameters can be found in Tab.2.

\section{Hydrograph response to extreme precipitation}

All the springs show a clear spike related to the rapid infiltration of storm water produced by Vaia (Fig. 4). Pradidali spring shows the fastest recovery to pre-event discharge (55 days) (Tab. 3). Recovery of the discharge to pre-event values takes 88 days for the Acq1 spring and 116 days for the Acq2 spring. This difference in recovery time can be explained with the fact that the storm occurred during the quickflow recession stage for the Pra spring, during mixed flow for the Acq1 spring and during the slow flow recession stage for the Acq2 spring (Fig. 4), therefore producing a faster or slower release of the storm wave. This hypothesis is supported also by the delayed response of the springs to the storm flood wave. A very fast discharge response to the storm peak is manifested in the Pradidali hydrograph, contrary to the other springs that show a delayed peak after 8 days.

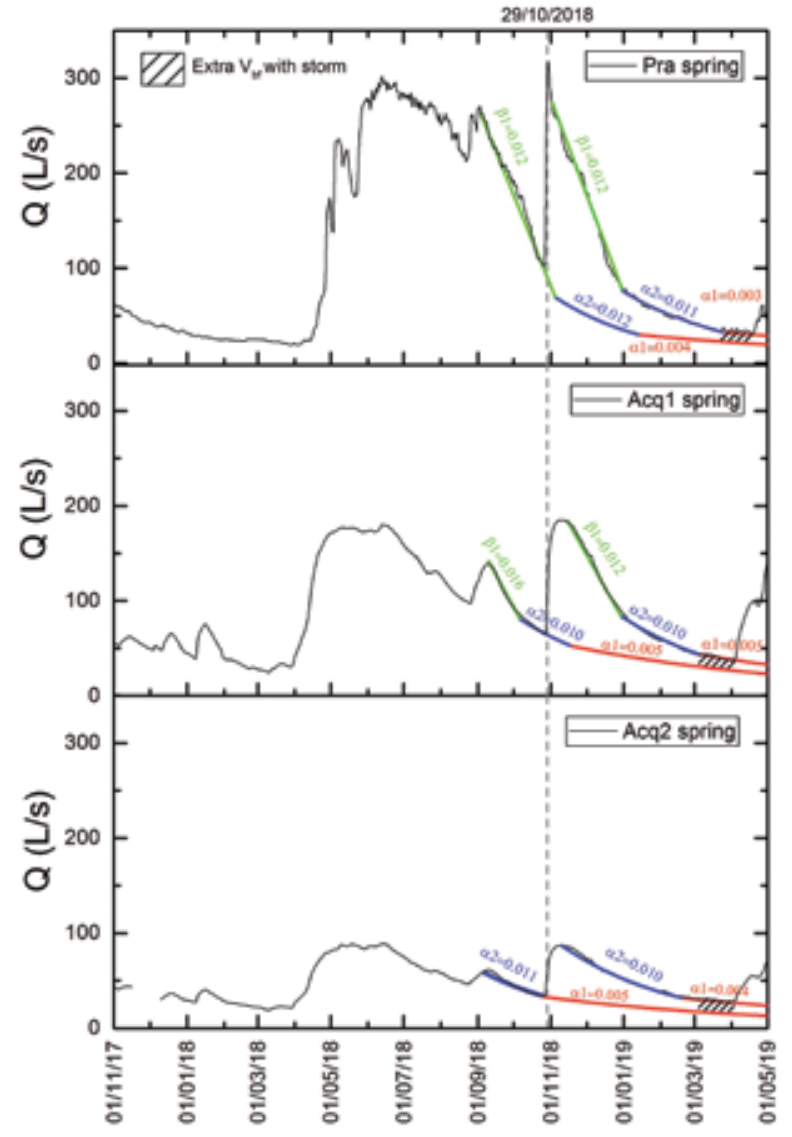

Fig. 4 - Hydrographs of the monitored springs. The master curves previously build for each spring (Fig.3) were joined to the recession phase which started in September 2018 (interrupted by the storm arrival) in order to show how the 2018-2019 winter recession curve would have continued without the storm influence.

Fig. 4 - Idrogrammi delle sorgenti monitorate. Le curve di master precedentemente costruite (Fig.3) sono state giuntate alla recessione iniziata a Settembre 2018 (interrotta dall'arrivo della tempesta) per confrontare come sarebbe proseguita la recessione durante l'inverno 2018-2019 senza l'influsso della tempesta.

Tab. 2 - Recession parameters and flow components identified for the monitored springs.

Tab. 2 - Parametri di recessione e componenti del flusso identificate per le sorgenti monitorate.

\begin{tabular}{|c|c|c|c|c|c|c|}
\hline Spring code & Flow type & Equation type & $\begin{array}{c}\text { MRC Recession } \\
\text { curve parameters } \\
{[1 / \text { day }]}\end{array}$ & $\begin{array}{c}\mathrm{MRC}_{0} \text { at the } \\
\text { beginning of } \\
\text { recession } \\
{[\mathrm{L} / \mathrm{s}]}\end{array}$ & $\begin{array}{c}\text { Storm Recession } \\
\text { curve parameters } \\
{[1 / \text { day }]}\end{array}$ & $\begin{array}{c}\mathrm{Q}_{0} \text { at the } \\
\text { beginning of } \\
\text { storm recession } \\
{[\mathrm{L} / \mathrm{s}]}\end{array}$ \\
\hline \multirow{3}{*}{ Pra } & $\begin{array}{l}\text { Quickflow } \\
\text { (conduit flow) }\end{array}$ & $\mathrm{Qt}=\mathrm{Q}_{0}(1-\beta \mathrm{t})$ & $\beta_{1}=0.012$ & 262 & $\beta_{1}=0.012$ & 274 \\
\hline & Mixed flow & $\mathrm{Qt}=\mathrm{Q}_{0} \mathrm{e}-\alpha_{2} \mathrm{t}$ & $\alpha_{2}=0.012$ & 68 & $\alpha_{2}=0.011$ & 76 \\
\hline & $\begin{array}{l}\text { Baseflow (diffuse } \\
\text { flow) }\end{array}$ & $\mathrm{Qt}=\mathrm{Q}_{0} \mathrm{e}-\alpha_{1} \mathrm{t}$ & $\alpha_{1}=0.004$ & 30 & $\alpha_{1}=0.003$ & 32 \\
\hline \multirow{3}{*}{ Acq1 } & $\begin{array}{l}\text { Quickflow } \\
\text { (conduit flow) }\end{array}$ & $\mathrm{Qt}=\mathrm{Q}_{0}(1-\beta \mathrm{t})$ & $\beta_{1}=0.016$ & 139 & $\beta_{1}=0.012$ & 185 \\
\hline & Mixed flow & $\mathrm{Qt}=\mathrm{Q}_{0} \mathrm{e}-\alpha_{2} \mathrm{t}$ & $\alpha_{2}=0.010$ & 81 & $\alpha_{2}=0.010$ & 82 \\
\hline & $\begin{array}{l}\text { Baseflow (diffuse } \\
\text { flow) }\end{array}$ & $\mathrm{Qt}=\mathrm{Q}_{0} \mathrm{e}-\alpha_{1} \mathrm{t}$ & $\alpha_{1}=0.005$ & 52 & $\alpha_{1}=0.005$ & 44 \\
\hline \multirow[b]{2}{*}{ Acq2 } & Mixed flow & $\mathrm{Qt}=\mathrm{Q}_{0} \mathrm{e}-\alpha_{2} \mathrm{t}$ & $\alpha_{2}=0.011$ & 61 & $\alpha_{2}=0.010$ & 87 \\
\hline & $\begin{array}{l}\text { Baseflow (diffuse } \\
\text { flow) }\end{array}$ & $\mathrm{Q} t=\mathrm{Q}_{0} \mathrm{e}-\alpha_{1} \mathrm{t}$ & $\alpha_{1}=0.005$ & 34 & $\alpha_{1}=0.004$ & 32 \\
\hline
\end{tabular}


Tab. 3 - Parameters that reflect the passage and release of the storm water. *The volume refers to the last month (31 days) of baseflow before the new recharge input. Tab. 3 - Parametri che riflettono il passaggio e il rilascio dell'acqua della tempesta. * I volumi sono riferiti all'ultimo mese ( 31 giorni) del flusso di base prima del nuovo input di ricarica.

\begin{tabular}{|l|c|c|c|c|c|c|c|c|}
\hline Spring code & $\begin{array}{c}\text { Lag time from } \\
\text { precipitation } \\
\text { peak [days] }\end{array}$ & $\begin{array}{c}\text { Peak Q } \\
{[\mathrm{L} / \mathrm{s}]}\end{array}$ & $\begin{array}{c}\text { Pre-event Q } \\
{[\mathrm{L} / \mathrm{s}]}\end{array}$ & $\begin{array}{c}\text { Recovery to } \\
\text { pre-event Q } \\
{[\text { days }]}\end{array}$ & $\begin{array}{c}\text { Unaffected } \\
\text { baseflow } \\
\left.\text { volume* [m } \mathrm{m}^{3}\right]\end{array}$ & $\begin{array}{c}\text { Baseflow } \\
\text { volume* } \\
\text { after storm } \\
{\left[\mathrm{m}^{3}\right]}\end{array}$ & $\begin{array}{c}\text { Extra } \\
\text { baseflow } \\
\text { volume } \\
{\left[\mathrm{m}^{3}\right]}\end{array}$ & $\begin{array}{c}\text { Baseflow } \\
\text { volume } \\
\text { increase } \%\end{array}$ \\
\hline Pra & $<1$ & 317 & 101 & 55 & 58468 & 90568 & 32100 & $55 \%$ \\
\hline Acq1 & 8 & 185 & 64 & 88 & 76863 & 109770 & 32907 & $43 \%$ \\
\hline Acq2 & 8 & 87 & 33 & 116 & 43042 & 79683 & 36641 & $85 \%$ \\
\hline
\end{tabular}

The recession analysis performed after storm shows that the recession coefficients of the springs remain more or less unaltered compared to the average parameters found with the MRCs, therefore the recession coefficients reflect inherited aquifer characteristics. The effect of the storm is manifested in a shifting of time of several months of the recession stages. For instance, the Pradidali spring, in normal conditions would have reached baseflow in the middle of January, whereas the baseflow beginning is shifted to the end of March. For Acq1, baseflow would have started in the end of November and is moved further to March. Compared to unaffected conditions, all the springs show a rising of the baseflow (Fig. 4) indicating that the storm water is able to reach the saturated zone of the aquifer. The volume difference between the baseflow in normal conditions and the baseflow after the storm can be considered as a measure of the impact of the storm on the groundwater reserves. The baseflow volume increase is similar (Tab. 3) and is comprised between $32100 \mathrm{~m}^{3}$ at the Pra spring and $36641 \mathrm{~m}^{3}$ at the Acq 2 spring. Considering the percentage increase compared to normal conditions, an average baseflow increase of $61 \%$ was found for the monitored springs, with the highest increase in the Acq2 spring (85\%).

\section{Conclusions}

Exceptional storm events can be interesting because they can significantly affect the groundwater system allowing to gain insights into the aquifers characteristics. Results from this work show that the "Vaia" storm recharged the groundwater system for several months, causing a delay of the spring hydrograph recession. This additional recharge sustains baseflow in the following dry season and thus is crucial both for water resources utilization and for ecological purposes. The results of this work should be intended as a preliminary understanding of the hydrological processes, as several years of discharge data are usually required for a good statistical accuracy. Future work will be focused in understanding if this additional recharge input will contribute to baseflow even in the following recession (2019-2020). It could also be interesting to investigate the effect of precipitation extremes in different saturation states, for instance with rain-on-snow conditions. With climate change, precipitation extremes are predicted to intensify in the alpine region, so understanding their influence on the spring discharge becomes mandatory for water resources management. Also, climate change models suggest that extreme events will maintain their seasonality. If this is the case, the presented study suggests that baseflow increase due to autumn precipitation extremes could possibly compensate the predicted groundwater shortages.

Acknowledgment: We would like to thank the Geological Survey of the Autonomous Province of Trento for supporting the research. Funding: This work was supported by Fondazione CARITRO: [Grant Number 2017.0411].

\section{REFERENCES}

Amit H, Lyakhovsky V, Katz A, Starinsky A, Burg A (2002) Interpretation of spring recession curves. Groundwater 40:543-551

Asadieh B, Krakauer, N Y (2015) Global trends in extreme precipitation: climate models versus observations. Hydrology and Earth System Sciences 21:5863-5874

Baedke S J, Krothe N C (2001) Derivation of effective hydraulic parameters of a karst aquifer from discharge hydrograph analysis. Water Resources Research 37:13-19

Beniston M (2012) Is snow in the Alps receding or disappearing? Wiley Interdisciplinary Reviews: Climate Change 3:349-358

Bonacci O (1993) Karst springs hydrographs as indicators of karst aquifers. Hydrological Sciences Journal 38:51-62

Brönnimann S, Rajczak J, Fischer E M, Raible C, Rohrer M, Schär C (2018) Changing seasonality of moderate and extreme precipitation events in the Alps. Natural Hazards and Earth System Science 18: 2047-2056

Buczyński S (2018) Temporal variability of springs in catchment areas located in the Sudeten Mountains. Hydrology Research 49:780-793

Calanca P (2007) Climate change and drought occurrence in the Alpine region: how severe are becoming the extremes?. Global and Planetary Change 57:151-160

Chirici G, Giannetti F, Travaglini D, Nocentini S, Francini S, D’Amico G, ... \& Tonner J (2019) Damage inventory after the" Vaia" storm in Italy. Forest@16:3-9

Confortola G, Soncini A, \& Bocchiola D (2013) Climate change will affect hydrological regimes in the Alps. A case study in Italy. Journal of Alpine Research 101-3 
Dankers R, Arnell N W, Clark D B, Falloon P D, Fekete B M, Gosling, S N, Stacke T (2014) First look at changes in flood hazard in the Inter-Sectoral Impact Model Intercomparison Project ensemble. Proceedings of the National Academy of Sciences 111:3257-3261

Fiorillo F (2009) Spring hydrographs as indicators of droughts in a karst environment. Journal of Hydrology 373:290-301

Gobiet A, Kotlarski, S, Beniston M, Heinrich G, Rajczak J, Stoffel M (2014) $21^{\text {st }}$ century climate change in the European Alps-a review. Science of the Total Environment 493:1138-1151

Kresic N, Bonacci O (2010) Spring discharge hydrograph. In Groundwater hydrology of springs (pp. 129-163). Butterworth-Heinemann.

Kron W, Löw P, Kundzewicz Z W (2019) Changes in risk of extreme weather events in Europe. Environmental Science \& Policy 100: 74-83.

Lucianetti G, Mazza R, Mastrorillo L (2019) Hydrogeology of a high Alpine carbonate aquifer (Pale di San Martino, Dolomites, Northern Italy). Journal of Maps 15:448-459

Malík P, Vojtková S (2012) Use of recession-curve analysis for estimation of karstification degree and its application in assessing overflow/underflow conditions in closely spaced karstic springs. Environmental earth sciences 65:2245-2257
Malik P (2015) Evaluating Discharge Regimes of Karst Aquifers. In Z. Stevanovic', Karst Aquifers - Characterization and Engineering. Springer International Publishing, Switzerland.

Milanovic P (1976) Water regime in deep karst: Case study of the Ombla Spring drainage area. Karst hydrology and water resources 1:165-191

Padilla A, Pulido-Bosch A, Mangin A (1994) Relative importance of baseflow and quickflow from hydrographs of karst spring. Groundwater 32:267-277

Trenti A (2018) Perturbazione eccezionale del 27- 29 ottobre 2018. Available from https://content.meteotrentino.it/analisiMM/2018_ perturbazione_ottobre.pdf last accessed 16/10/2019

Yang M, Chen X, Cheng C S (2016) Hydrological impacts of precipitation extremes in the Huaihe River Basin, China. SpringerPlus 5:1731

Zhang J, Felzer B S, Troy T J (2016) Extreme precipitation drives groundwater recharge: the northern high plains aquifer, central United States, 1950-2010. Hydrological Processes, 30(14): 2533-2545 